\title{
CHU SINH VÀ NHỮNG YẾU TỐ NGUY CƠ TỬ MẸ
}

\author{
Khu Thị Khánh Dung \\ Bệnh viện Nhi Trung ương
}

\section{1. ĐẠI CƯƠNG}

\section{Định nghĩa giai đoạn chu sinh}

Tổ chức YTTG và Hội Sản phụ khoa Canada định nghĩa giai đoạn chu sinh từ 22 tuần tuổi thai đến 7 ngày sau khi sinh.

Chăm sóc bà mẹ mang thai không đầy đủ tại các nước đang phát triển sẽ dẫn đến các nguy cơ cao cho bà mẹ và trẻ em; có thể gây ra những biến chứng khi sinh cho me và trẻ sơ sinh như: bệnh não thiếu oxy (HIE), hạ đường huyết, tăng bilirrubin gián tiếp, và các nhiễm trùng nặng ...

\section{MÔI TRƯờNG CHU SINH ẢNH HƯởNG ĐẾN SƠ SINH NHƯ THẾ NÀO?}

Thai nhi phụ thuộc hoàn toàn môi trường trong tử cung của mẹ về hô hấp, dinh dướng, có mối liên quan chặt chẽ với chuyển hóa của mẹ, tuần hoàn và những yếu tố môi trường tác động đến người mẹ.

Đặc biệt trẻ sơ sinh không có khả năng thích nghi và biến đổi cho phù hợp môi trường xung quanh hoặc những stress của mẹ. Vì vậy nếu mẹ có những chấn thương tâm lý, bệnh tật có thể sẽ ảnh hưởng đến suốt giai đoạn mang thai và kể cả sau khi sinh ra. Những bà mẹ có nguy cơ cao có ảnh hưởng rõ rệt đến thai nhi chính vì vậy việc chăm sóc trước sinh thường xuyên là công việc thường quy.

Điểm mấu chốt trong chăm sóc trước sinh là phát hiện được vấn đề có thể sẽ xảy ra khi sinh để có biện pháp dự phòng hoặc can thiệp kịp thời.
Theo dõi trẻ sau sinh cũng rất quan trọng để có thể hỗ trợ trẻ ngay khi cần thiết.

Trong giai đoạn chu sinh, mối liên quan giữa mẹ và con qua rau thai là chủ yếu vì vậy việc cung cấp đủ dinh dưỡng, oxy qua rau thai là rất cần thiết và để đạt được điều đónguồn dinh dưỡng của mẹ phải bảo đảm. Đầu tiên rau thai bài tiết ra các hormon nội tiết làm thay đổi các chuyển hóa của mẹ, đặc biệt tăng chuyển hóa glucose và amino axit truyền cho thai nhi, đặc biệt giai đoạn nửa sau của thai kỳ. Sau đó rau thai sẽ vận chuyển các chất dinh dưỡng thiết yếu từ mẹ qua tuần hoàn thai nhi và ngược lại mang các chất thải về hệ thống của mẹ.

Đây là con đường duy nhất từ thai nhi đến mẹ

Hô hấp của thai nhi cũng phụ thuộc hoàn toàn vào chức phận của rau thai, $\mathrm{O}_{2}, \mathrm{CO}_{2}$ qua màng rau thai bằng cách khuếch tán theo tỷ lệ của $\mathrm{PO}_{2^{\prime}}$ $\mathrm{PCO}_{2}$ của mẹ. Rau thai là trung gian vận chuyển dinh dưỡng từ mẹ sang con và mẹ là nguồn dự trữ. Trao đổi chất mẹ-con hoàn toàn phụ thuộc vào tuần hoàn mẹ, hiệu quả của trao đổi này là do hệ thống tim mạch của mẹ và độ tưới máu của rau thai và chức năng của bánh rau. Bánh rau có thể không phát triển khi bị ảnh hưởng của ethanol, giảm hoặc gián đoạn tưới máu của bánh rau gây bánh rau nhỏ, bị giập vỡ, chức phận bánh rau không bình thường. Dinh dưỡng và bệnh tật của mẹ cũng ảnh hưởng tới kích thước bánh rau và chức năng vận chuyển của nó.

\section{NHỮNG YẾU TỐ TỪ PHÍA ME ẢNH HƯởNG ĐẾN THAI NHI}

Tại các nước đang phát triển, nơi mà các bà 
mẹ mang thai không tiếp cận được đầy đủ với dịch vụ y tế, các bệnh mạn tính của mẹ dẫn tới các biến chứng trong thời kỳ mang thai thường không được phát hiện. Phổ biến nhất có thể dẫn đến sinh non, hoặc một số bệnh không được điều trị dẫn đến đứa trẻ có thể chậm phát triển tinh thần vận động. Cần sàng lọc cho bà mẹ bao gồm:

Con của bà mẹ đái tháo đường: thường kết hợp với thai to do cường insulin máu, nguy cơ cao ngạt, hạ đường huyết và mẹ không điều trị con có thể bị thai chết lưu. Tỷ lệ đái tháo đường của mẹ và thai nhi tăng trên thế giới , tại Mỹ 2-7\% mẹ có thai bị đái tháo đường.

Bệnh tuyến giáp của mẹ: cũng ảnh hưởng đến thai nhi. Thai nhi phụ thuộc hoàn toàn nồng độ T3, T4 trong 3 tháng đâu mang thai. Khi được 8-10 tuần tuyến giáp của thai nhi bắt đầu tập trung iodine và T4. Từ tháng thứ 4 thai nhi hoàn toàn không phụ thuộc vào tình trạng của mẹ. Khoảng 24 tuần tuổi thai các receptor Abs TSH,TSIs qua rau thai và kích thích tuyến giáp thai nhi, iodine vận chuyển tới thai nhi qua rau thai tuần 10-12 tuyến giáp thai nhi đã tự tập trung iodine và độc lập với chức năng tuyến giáp của me. Hormon tuyến giáp của mẹ đóng vai trò quan trọng trong phát triển thần kinh của thai nhi trong 3 tháng đầu. Nếu mẹ bị suy giáp cần phải được điều trị thay thế , nó sẽ được thai nhi hấp thu tốt và như vậy sẽ giảm được nguy cơ cho trẻ. Thiếu iodine của mẹ sẽ ảnh hưởng trực tiếp đến thai nhi và có thể là nguyên nhân dẫn đến thai chết lưu.

Phenylketonuria (PKU) là bệnh di truyền lặn thuộc nhóm bệnh di truyền chuyển hóa đơn gen do thiếu khuyết enzyme phenylalanine hydroxylase, trẻ thường đẻ cân nặng thấp có thể kèm dị tật tim,... nếu không được điều trị sớm trẻ sẽ bị tổn thương thần kinh gây bại não, chậm phát triển tinh thần vận động. Bà mẹ bị bệnh này cần tuân thủ chế độ ăn, đảm bảo nồng độ phenylalanine trong máu ở giới hạn $2-8 \mathrm{mg} / \mathrm{dL}$ trước khi mang thai 3 tháng và trong suốt thời kỳ mang thai.

Mẹ bị bệnh thận: Khi mang thai sự thay đổi chức năng thận của bà mẹ rất sớm, tăng tưới máu ở thâan từ 35- $60 \%$ trong 3 tháng đâu thai kỳ và giảm dần từ tháng thứ 4 cho đến lúc sinh. Sự thay đổi này bao gồm cả tăng mức lọc cầu thận, tăng tưới máu và giảm sức cản mạch máu thận và kích thích hệ thống renin-angiotensin-aldosterone.

Tổn thương thận thường do nhiểm khuẩn tiết niệu, bệnh viêm cầu thận, cao huyết áp. Những biến chứng thường gặp là tiền sản giật. Suy thận cấp trên bà mẹ mang thai có thể dẫn đến tử vong mẹ và tử vong thai nhi

Mẹ bị các bệnh thần kinh: Các bà mẹ khi mang thai có thể là yếu tố khởi phát các bệnh sẵn có về thần kinh hoặc do kết hợp. Về sinh lý khi mang thai hormon thay đổi co thể ảnh hưởng đến rối loạn thần kinh cơ mạn tính có sẵn như động kinh, xơ hóa rải rác hệ thống thần kinh, ... những bệnh này có thể dẫn đến những nguy cơ cao cho thai nhi và sơ sinh tăng tỷ lệ xảy thai, đẻ non, chậm phát triển so với tuổi thai, dị tật bẩm sinh. Trẻ sinh ra ở những bà mẹ dùng thuốc chống co giật có thể bị suy hô hấp, giảm trương lực cớ, run giật, tăng thông khí, có thể rối loạn đông máu, gây xuất huyết.

Me bị mắc bệnh xơ cứng rải rác: thường có những ổ myelin rải rác khắp chất trắng của hệ thần kinh trung ương, là bệnh tự miễn của tế bào trung gian $T$ của hệ thống thần kinh. Con của các mẹ này có nguy cơ cao dị tật bẩm sinh, cân nặng thấp và chăm sóc chu sinh cần lưu ý khả năng tự nuôi con của mẹ để đề phòng các nguy cơ an toàn của trẻ.

Me bị Lupus: là bệnh tự miễn, ảnh hưởng tới nhiều cơ quan, mẹ có thể suy thận, tăng nguy cơ tiền sản giật, sẩy thai, thai chết lưu, đẻ non, chậm phát triển trong tử cung. Ảnh hưởng tới nhịp tim thai thường chậm, có thể có block nhĩ thất, cần đặt máy tạo nhịp ngay sau khi sinh.

Mẹ bị bệnh tim: Khi mang thai chức năng tuần hoàn thay đổi, tăng thể tích máu, hồng cầu, tăng nhịp tim tăng out put, sức cản mạch máu hệ thống giảm, những thay đổi này dẫn đến tăng tưới máu cho tử cung, tăng cung cấp oxy cho thai 
nhi. Khi bà mẹ mắc bệnh tim các thay đổi trên làm tăng gánh cho tim giảm tưới máu cho thai nhi và đặc biệt thai nhi sẽ bị ảnh hưởng từ các thuốc điều trị của mẹ.

Mẹ bị bệnh hô hấp: Khi có thai chức phận hô hấp của mẹ thay đổi để thích nghi thể tích phổi giảm tăng dự trữ oxy, tăng thông khí phút và nhịp thở. Khi chức năng hô hấp giảm dẫn đến thai nhi thiếu oxy. Một trong bệnh thường ảnh hưởng đến thai nhi nhất đó là hen, bệnh mẹ càng nặng ảnh hưởng đến thai nhi càng nhiều, nguy cơ cao cân nặng thấp, sinh non, đẻ mổ.

Bệnh xơ nang phổi của mẹ cũng gây những nguy cơ cho con, chậm phát triển trong tử cung, thai chết lưu, đẻ non... nguyên nhân do di truyền và nhiễm trùng của mẹ.

Hành vi của mẹ: hút thuốc, uống rượu, cocain

Mẹ hút thuốc: có thể dẫn đến thiếu dinh dưỡng của mẹ, thiếu máu, nguy cơ cao cho trẻ do tưới máu rau thai kém, co thắt mạch máu rau thai tăng nồng độ nicotin, carbon monoxide dẫn đến thiếu oxy mạn trong bào thai, chậm phát triển trong tử cung. Cần có tư vấn cho bà mẹ dừng thuốc lá trong 3 tháng đầu của thai kỳ trẻ có thể phát triển bình thường.

Mẹ nghiện rượu: nguy cơ cao cho trẻ chậm phát triển, sẩy thai, thai chết lưu, dị dạng mặt, rối loạn chức phận thần kinh và các dị tật khác. Hội chứng rượu thai nhi (FAS- fetal alcohol syndrome) thường biểu hiện: đẻ ngạt, chậm lớn, mặt bất thường, cằm nỏ, mũi thấp, môi trên mỏng, thiểu sản hàm, dị tật tim, thần kinh, tai... trẻ đẻ ra có thể co giật, khó nuốt, vận động không bình thường, ảnh hưởng đến trẻ lâu dài sau này.

Mẹ nghiện cocain: Cocain gây kích thích hệ thần kinh tăng co mạch, thở nhanh, tăng huyết áp cả mẹ và thai nhi. Con thường chậm lớn, vòng đầu nhỏ, bất thường hệ sinh dục, tổn thương rau thai, thai chết lưu suy hô hấp, hội chứng kích thích sơ sinh biểu hiện trẻ luôn bị kích thích và rối loạn chức năng tiêu hóa (NAS- Neonatal abstinence syndrome), nhồi máu não, ...
Dinh dưỡng của mẹ: Cần cung cấp đủ dinh dưỡng trong thời gian mang thai theo khuyến cáo của WHO. Mẹ suy dinh dưỡng ảnh hưởng trực tiếp đến thai nhi, con nguy cơ cân nặng thấp, và gặp nhiều biến chứng khi sinh. Mẹ béo phì BMI > 40 mẹ dễ bị cao huyết áp, tiểu đường, bệnh về tim mạch, nguy cơ viêm màng ối, thai chết lưu, sản giật, chảy máu sau sinh,... Con nguy cơ thai to, đẻ ngạt, hít phân su, ngạt trước sinh.

\section{NGUY CO TRONG GIAI ĐOAN CHU SINH ẢNH HƯởNG ĐẾN LÚC SINH}

Cao huyết áp (tiền sản giật hoặc sản giật), là những nguyên nhân gây bệnh nặng hậu quả lâu dài trẻ có thể để lại di chứng thần kinh. Tiền sản giật có thể dẫn đến bánh rau nuôi dưỡng kém nguy cơ sinh non.

Nhiễm trùng: STDs, Streptococcus B: là nguyên nhân nhiễm trùng sớm sơ sinh và tăng tử vong chu sinh.

Chấn thương: Khi sinh thường gặp với thai to, mẹ béo phì, ngôi ngược, bất thường khung chậu của mẹ, hoặc cắt tầng sinh môn khi sinh .... Chấn thương khi sinh không phải là nguyên nhân phổ biến nhưng khi bị xuất huyết não thấy khả năng di chứng cao. Một số chấn thương thần kinh ngoại biên như liệt đám rối cánh tay, ... có thể hồi phục nhưng mất nhiều thời gian.

\section{Tai biến sản khoa}

Chảy máu trong khi mang thai: xảy ra ở giai đoạn thứ 2 của thai kỳ có thể dẫn đến vỡ ối non, đẻ non, cân nặng thấp. Mẹ rau tiền đạo,

Vỡ ối sớm, rau tiền đạo, rau bám thấp, bất thường rau thai, sản giật, hội chứng HELLP (Hemolysis, Elevated, Liver enzymes. Low platelets), bất thường chức năng thận có thể gây chảy máu ở mẹ và nguy cơ cao thiếu máu, ngạt thai nhi.

\section{Nhiễm trùng giai đoạn chu sinh}

STIs: Nhiễm Herpes thường dẫn đến các di chứng thần kinh. Mẹ nhiễm lậu cầu không được điều trị thì có tới $30-50 \%$ trẻ sinh ra từ những bà 
mẹ này bị lậu mắt, $30 \%$ với những trẻ có mẹ mắc Chlamydia là một trong những nguyên nhân gây mù lòa sau này nếu không được điều trị sớm. Trên thế giới hàng năm khoảng 1000-4000 trẻ sinh ra bị mù do nguyên nhân trên.

Nhiễm khuẩn từ me sang con trong thời gian mang thai, lúc sinh qua đường sinh dục, đây là nguyên nhân gây nhiễm khuẩn sơ sinh sớm và làm tăng nguy cơ tử vong ở các nước đang phát triển.

Nhiễm liên cầu tan huyết $B$ khoảng 0-3,06/1000 ca đẻ sống ở các nước đang phát triển. Nhiễm GBS thường để lại các di chứng co giật, chậm phát triển tinh thần vận động, điếc, bại não ... Cần khám sàng lọc phát hiện nguy cơ ở những bà mẹ có sốt trước sinh, đẻ non <35 tuần, vỡ ối kéo dài $>18$ giờ và viêm màng ối

Nhiễm Listeria thường do chế độ ăn của me nấu không chín, thực phẩm không sạch. Mẹ có thể nhiễm cúm, các virus trong thời gian mang thai, có thể là nguyên nhân dẫn đến nhiễm trùng sơ sinh, viêm màng não mủ và để lại di chứng. Tỷ lệ này thường gặp cao ở các nước Mỹ Latinh do ăn ăn thực phẩm không sạch.

\section{Đẻ non}

Đẻ non (<37 tuổi thai) là vấn đề của toàn cầu. Yếu tố nguy cơ gây đẻ non bao gồm: bất thường hệ tiết niệu, chảy máu rau thai, con mẹ bị nghiện, mẹ bệnh mãn tính, cao HA, viêm màng ối, vỡ ối sớm, nhiểm khuẩn đường sinh dục. Đa thai cũng là một trong những nguyên nhân gây tỷ lệ biến chứng cao khi mang thai và khi sinh.

Hàng năm có khoảng 15 triệu trẻ sinh non thế giới, cứ 10 trẻ sinh ra có một trẻ đẻ non. Trên $60 \%$ trẻ sinh non ở các nước châu Phi và Nam Á, càng nghèo thì nguy cơ này càng cao.

Cần dùng corticosteroide cho bà mẹ mang thai từ tuần 24-34 có nguy cơ sinh non. Liều dùng 2 liều betamethasone $12 \mathrm{mg} /$ tiêm bắp $/ 24$ giờ/lần hoặc 4 liều dexamethasone $6 \mathrm{mg} / \mathrm{tiêm}$ bắp/12 giờ/lần.

\begin{tabular}{|l|l|}
\hline \multicolumn{2}{|c|}{ 10 nước có số lượng đẻ non cao nhất năm 2010 } \\
\hline India & $\mathbf{3 5 1 9 1 0 0}$ \\
\hline China & 1172300 \\
\hline Nigeria & 773600 \\
\hline Pakistan & 748100 \\
\hline Indonesia & 675700 \\
\hline United States of America & 517400 \\
\hline Bangladesh & 424100 \\
\hline Philippines & 348900 \\
\hline Democratic Republic of the Congo & 341400 \\
\hline Brazil & 279300 \\
\hline
\end{tabular}

Các nguy cơ từ cuộc đẻ tới thai nhi

Cơn co tử cung: cơn co tử cung mạnh giảm tưới máu thai nhi, ảnh hưởng trao đổi $\mathrm{O}_{2}$ qua rau thai.

Chăm sóc trước sinh, tiêm chủng không đầy đủ, không kiểm soát được nhiễm khuẩn sinh dục của mẹ... là những nguyên nhân ảnh hưởng đến sự phát triển không bình thường cho trẻ sinh non.

Khi nào cần sàng lọc phát hiện nhiễm khuẩn cho bà mẹ mang thai.
Cân nhắc khi bà mẹ có những dấu hiệu sau:

- Sốt

- Mẩn đỏ

- Đau bụng

- Sốt rét

- Nôn, tiêu chảy

- Dịch âm đạo có mùi hôi 
- Tiểu ít

- Đau khớp

Những di chứng của trẻ sau này và đặc biệt trong giai đoạn sơ sinh chịu nhiều ảnh hưởng từ giai đoạn chu sinh do chăm sóc trước sinh không đầy đủ, không phát hiện để phòng và điều trị kịp thời. Chăm sóc chu sinh cần được tổ chức tốt cho các bà mẹ có nguy cơ cao và cần được sàng lọc trước sinh và phát hiện sớm những trẻ nguy cơ để can thiệp.

\section{TÀI LIỆU THAM KHẢO}

1. American Academy of Pediatrics, Committee on Children with Disabilities, (2001). Role of the paediatrician in family-centered early intervention services. Pediatrics 2011;107(5):1155-7.

2. Centers for Disease Control and Prevention. Developmental disabilities increasing in US: www.cdc.gov/features/dsdev_disabilities.

3. WHO, 2012. Congenital anomalies: Fact sheet no. 370: http://www.who.int/mediacentre/ factsheets/fs370/en/.
4. Le Doaré $K$, Bland $R$, Newell ML. Neurodevelopment in children born to HIV infected mothers by infection treatment status. Pediatrics 2012;130(5): e1326-44.

5. Swanson EC, Schleiss MR. Congenital cytomegalovirus infection: New prospects for prevention and therapy. PediatrClin N Am 2013; 60(2): 335-49.

6. WHO, 2013. Rubella and congenital rubella syndrome (CRS):

www.who.int/immunization_monitoring/diseases/ rubella/en/

7.WHO, 2013. Over a million pregnant women infected with syphilis worldwide: www.who.int/ entity/reproductivehealth/topics/rtis/syphilis/ pregnancy.

8. WHO. Feto-maternal nutrition and low birth weight:

www.who.int/nutrition/topics/feto_maternal/en/

9. Centers for Disease Control and Prevention. ABCs Report: Group B Streptococcus, 2012: http:// www.cdc.gov/abcs/reports-findings/survreports/ gbs12.html. 